\title{
Scientific literacy and science learning achievement at junior high school
}

\author{
Jufrida Jufrida $^{1}$, Fibrika Rahmat Basuki², Wawan Kurniawan ${ }^{3}$, Miko Danu Pangestu ${ }^{4}$, Olva Fitaloka \\ 1,2,3,4Physics Education Department, Universitas Jambi, Indonesia \\ ${ }^{5}$ Mathematic Education Department, Universitas Jambi, Indonesia
}

\section{Article Info \\ Article history: \\ Received Aug 30, 2019 \\ Revised Oct 29, 2019 \\ Accepted Nov 21, 2019}

\section{Keywords:}

Correlation

Junior high school

Science learning achievement

Scientific literacy

\begin{abstract}
Scientific literacy is the ability which must be owned by the students to analyze and apply the concept of science in solving daily life problem. This research aims to know the correlation between scientific literacy and science learning achievement at State Junior High Schools. This research used a quantitative approach with correlational type. The population of this research were 428 grade IX students at State Junior High Schools within the District of Jaluko Muaro Jambi. The samples was 138 students. The technique of selecting samples was random sampling. The instruments used were the test of science literacy and the test of science learning achievement. Hypothesis test was conducted by using rank spearman correlation test with the assistance of SPSS 21. The results show the average score of scientific literacy is 33.7 (medium category) and the average score of science learning achievement is 21.5 (very low category). The result of the correlation test obtains Sig value 0.00 then $\mathrm{H}_{\mathrm{o}}$ is rejected. It can be concluded that there is a significant correlation between scientific literacy and science learning achievement at State Junior High School within Muaro Jambi District. Science learning is expected to develop students' science literacy so that it can improve science learning achievement.
\end{abstract}

Copyright (c) 2019 Institute of Advanced Engineering and Science. All rights reserved.

\section{Corresponding Author:}

Fibrika Rahmat Basuki,

Physics Education Department,

Universitas Jambi,

Jambi-Muara Bulian Street KM 15 Mendalo Indah, Jambi, Indonesia, 36361

Email: fibrikabika@yahoo.com

\section{INTRODUCTION}

Scientific literacy is one of the most important skills and should be strengthened by the students. Students with scientific literacy skills will be able to apply the knowledge learned to solve problems in good everyday life. Scientific literacy is a person's ability to use scientific knowledge and processes to make decisions related to the Universe [1-3]. Scientific literacy plays an important role in everyday life. In the $21^{\text {st }}$ century, it takes people who have scientific knowledge and about the latest technological issues [4]. Science Learning aims to develop skills and creativity based on scientific knowledge relevant to everyday life and decision-making for problem-solving [5]. Aspects of scientific literacy, based on the Program for International Students Assessment (PISA) 2015 Aspects of scientific literacy consist of aspects of context, aspects of scientific competence, aspects of knowledge, and aspects of attitude. Scientific literacy is the key to learning success in education in children aged 15 years [6]. Science is a way of thinking, science as a way to investigate, and the interaction between science, technology, society, and scientific literacy, science interaction with the environment $[7,8]$.

In 2015 Indonesian students ' scientific literacy was ranked at 62 from 70 countries with a score of 403. This score is still far below the international average score that Program for International Students Assessment (PISA) has set to be 500 [6]. The results of the mapping by, Trends in International Mathematics 
and Science Studies (TIMSS) year 2015 in the field of scientific literacy Indonesia still be ranked 45 from 48 countries [9]. These results show the average Indonesian scientific literacy is below the international average score. The lack of scientific literacy in Indonesia reflects that students in Indonesia are largely unable to analyse and apply the concept to solve a problem. Students tend to memorize the concept but are still lacking in their use of knowledge [10]. Learning that tends to memorize concepts, theories and laws alone causes students difficulty in applying knowledge gained in everyday life [11].

Internal factors and external factors influence the success of learning science. Internal factors arise from within the child itself, such as health, mental, intelligence, student motivation, participation, involvement in the learning process, organization of the learning process and the relationship between students and teaching. External factors are factors originating from outside the child, such as family, community, friends, teachers, media, facilities, and environmental infrastructure [12-14]. The problem of low students' scientific literacy skills can be solved by implementing constructivist science-learning models/methods/strategies, learning resources and learning programs that support them to have Scientific literacy skills. The environment and the classroom atmosphere play an important role in supporting students' scientific literacy $[15,7]$.

Based on the preliminary study that was performed at 1 State Junior High School, 7 State Junior High School, and 17 State Junior High School of Muaro Jambi obtained the knowledge that the understanding of the science concept of students is still low, students struggle to solve the problem of applying mathematical equations, Students are not accustomed to solving problems related to the science, students are never trained to solve scientific literacy questions, how to learn students still memorize the material submitted by the teacher, and students rarely study independently at home. This has an impact on low student science learning outcomes. The lack of student learning results shows that the learning process in school is less practicing student scientific literacy. The results of the research of [16] show that there is a link between scientific literacy skills with study achievement in $11^{\text {th }}$-grade science program State High School all over Makassar City. The research results [17] shows that there is a positive relationship between scientific literacy skills and learning outcomes, which means that higher scientific literacy skills in the 11th grade in high school, the higher the student learning outcomes despite the value of the correlation between the two in the low category.

\section{METHOD}

This research uses quantitative approaches with correlational type. Correlational research is a method of research that investigates the relationship between two or more variables [18]. This research investigated the scientific literacy relationship and the students' science learning outcomes. The population in this research was $9^{\text {th }}$-grade state junior high school students who have "A" accreditation throughout Jaluko subdistrict, Jambi, Indonesia amounted to 428 students. Sampling techniques used random sampling technique. The number of sample taken is 138 students presented in Table 1.

Table 1. Number of population and research samples

\begin{tabular}{clcc}
\hline No & \multicolumn{1}{c}{ Schools } & Population & Samples \\
\hline 1 & State Junior High School 1 Muaro Jambi & 154 students & 42 students \\
2 & State Junior High School 7 Muaro Jambi & 198 students & 55 students \\
3 & State Junior High School 17 Muaro Jambi & 76 students & 41 students \\
& Total & 428 students & 138 students \\
\hline
\end{tabular}

The research instruments used are scientific literacy tests and study results tests. Scientific literacy test consists of 11 essays, seven questions of multiple choices and three questions with the answer "yes" or "no". The Scientific literacy test has been validated and in empirical tests with very high reliability of 0.85 .

Grid of science literation is presented in Table 2. Test results of science study as much as 40 questions of the multiple-choice consisting of 23 questions of grade $7^{\text {th }}, 7$ about grade $8^{\text {th }}$, and 10 questions of grade $9^{\text {th }}$. Test results were validated and empiric test with a very high reliability of 0.81 . 
Table 2. Grids of scientific literacy

\begin{tabular}{|c|c|c|c|c|c|c|c|}
\hline \multirow{3}{*}{ Topics } & \multirow{3}{*}{$\begin{array}{l}\text { Question's } \\
\text { Number }\end{array}$} & \multicolumn{6}{|c|}{ Aspects of Scientific literacy } \\
\hline & & \multicolumn{3}{|c|}{ Knowledge (P) } & \multicolumn{3}{|c|}{ Competence $(\mathrm{K})$} \\
\hline & & $\mathrm{P} 1$ & $\mathrm{P} 2$ & $\mathrm{P} 3$ & $\mathrm{~K} 1$ & $\mathrm{~K} 2$ & K3 \\
\hline \multirow[t]{4}{*}{ Water Treatment } & 1 & & $\sqrt{ }$ & & $\sqrt{ }$ & & \\
\hline & 2 & & $\sqrt{ }$ & & & & $\sqrt{ }$ \\
\hline & 3 & & & $\sqrt{ }$ & $\sqrt{ }$ & & \\
\hline & 4 & & $\sqrt{ }$ & & $\sqrt{ }$ & & \\
\hline \multirow[t]{2}{*}{ Fire } & 5 & $\sqrt{ }$ & & & & $\sqrt{ }$ & \\
\hline & 6 & & & $\sqrt{ }$ & & $\sqrt{ }$ & \\
\hline Month Phase & 7 & $\sqrt{ }$ & & & $\sqrt{ }$ & & \\
\hline \multirow[t]{3}{*}{ Fish Preservative } & 8 & & & $\sqrt{ }$ & $\sqrt{ }$ & & \\
\hline & 9 & $\sqrt{ }$ & & & & $\sqrt{ }$ & \\
\hline & 10 & & & $\sqrt{ }$ & & $\sqrt{ }$ & \\
\hline The Size of Sky Objects & 11 & $\sqrt{ }$ & & & & & $\sqrt{ }$ \\
\hline Moon Circulation & 12 & $\sqrt{ }$ & & & $\sqrt{ }$ & & \\
\hline \multirow[t]{2}{*}{ Weather } & 13 & $\sqrt{ }$ & & & & & $\sqrt{ }$ \\
\hline & 14 & & & $\sqrt{ }$ & & & $\sqrt{ }$ \\
\hline \multirow[t]{4}{*}{ Disaster Threats } & 15 & & & $\sqrt{ }$ & $\sqrt{ }$ & & \\
\hline & 16 & & $\sqrt{ }$ & & & & $\sqrt{ }$ \\
\hline & 17 & & & $\sqrt{ }$ & $\sqrt{ }$ & & \\
\hline & 18 & & & $\sqrt{ }$ & $\sqrt{ }$ & & \\
\hline \multirow[t]{3}{*}{ Beautiful Park } & 19 & & & $\sqrt{ }$ & & & $\sqrt{ }$ \\
\hline & 20 & & & $\sqrt{ }$ & & $\sqrt{ }$ & \\
\hline & 21 & & & $\sqrt{ }$ & & $\sqrt{ }$ & \\
\hline
\end{tabular}

Source: Pande et.al (2015)

Description:

$\mathrm{P} 1$ = Content knowledge,

$\mathrm{P} 2$ = Procedural knowledge,

$\mathrm{P} 3=$ Epistemic knowledge,

$\mathrm{K} 1$ = Conference on explaining scientific phenomena,

$\mathrm{K} 2$ = Competence of identifying scientific problems,

$\mathrm{K} 3$ = Competency using scientific evidence

The hypothesis test is performed by using nonparametric statistics with a correlation test Rank Spearman. Rank Spearman test is done with the help of SPSS 21 with a significance level of 5\%. Ho's acceptance criteria, if the significance of the $<0.05$ is then Ho is rejected, it can be concluded that there was a significant correlation between scientific literacy and Student science learning outcomes in the state Junior high school throughout Jaluko subdistrict, Jambi, Indonesia. The level of association between scientific literacy and student science learning results was determined by the correlation coefficient referring to Table 3.

Table 3. Correlation coefficient

\begin{tabular}{ll}
\hline Interval & Level of Correlation \\
\hline $0.00-0.02$ & Very weak correlation \\
$0.21-0.40$ & Weak correlation \\
$0.41-0.60$ & Medium correlation \\
$0.61-0.80$ & Strong correlation \\
$0.81-1.00$ & Very strong correlation \\
\hline
\end{tabular}

\section{RESULT AND DISCUSSION}

3.1. Description of scientific literacy data and learning outcomes

The data of scientific literacy is obtained through a test that is given to students grades 9th 1 State Junior High School, 7 State Junior High School, and 17 State Junior High School. The average of 33.7 scientific literacy results is in the lower category in detail can be seen in Table 4 . The frequency distribution and percentage of scientific literacy can be seen in Table 5.

Table 4. The results of student scientific literacy

\begin{tabular}{ccccccc}
\hline $\mathrm{N}$ & Mean & Maximum & Minimum & Median & Modus & Standard of Deviation \\
\hline 38 & 33.7 & 69.0 & 4.5 & 31.8 & 25.0 & 14.80 \\
\hline
\end{tabular}


In Table 5, it appears that $50 \%$ of students ' scientific literacy skills are low and $22 \%$ of students ' scientific literacy skills are very low. Scientific literacy is must-have ability for students and the key to successful learning in children's education at the age of 15 years. The learning of science that is orientated on literacy designed to develop the scientific attitude, scientific skills, reasoned ability, the ability of students in conducting a scientific investigation, science process skills, and confidence [19]. The lack of scientific literacy reflects students not accustomed to solving problems related to science, never trained to solve scientific literacy questions, how to learn students still memorizing the material submitted by the teacher.

Table 5. Frequency distribution and prensente of scientific literacy

\begin{tabular}{cccc}
\hline Score Interval & Frequency & Percentage & Category \\
\hline $81-100$ & 0 & $0 \%$ & Very high \\
$61-80$ & 6 & $4 \%$ & High \\
$41-60$ & 33 & $24 \%$ & Medium \\
$21-40$ & 69 & $50 \%$ & Low \\
$0-20$ & 30 & $22 \%$ & Very Low \\
Total & 138 & $100 \%$ & \\
\hline
\end{tabular}

Scientific literacy is very important for students in understanding what is learned in school and is also very influential in the cognitive abilities of students [20,21]. Scientific literacy will ultimately be the result of learning science. In addition to scientific literacy tests, students are also given test results on science. The average of the science results of the 21.5 with very low categories in detail can be seen in Table 6 . Frequency distribution and percentage of learning outcomes can be seen in Table 7.

Table 6. Student Science learning outcomes

\begin{tabular}{ccccccc}
\hline $\mathrm{N}$ & Mean & Maximum & Minimum & Median & Modus & Standard of Deviation \\
\hline 138 & 21.5 & 74.4 & 2.5 & 15 & 15 & 16.24 \\
\hline
\end{tabular}

Table 7. Frequency distribution and precentage of learning outcomes science.

\begin{tabular}{cccc}
\hline Score Interval & Frequency & Percentage & Category \\
\hline $81-100$ & 0 & $0 \%$ & Very High \\
$61-80$ & 3 & $2 \%$ & High \\
$41-60$ & 21 & $15 \%$ & Medium \\
$21-40$ & 25 & $18 \%$ & Low \\
$0-20$ & 89 & $65 \%$ & Very Low \\
Total & 138 & $100 \%$ & \\
\hline
\end{tabular}

In Table 7 it appears that the achievement of science study $65 \%$ of respondents is in very low category. Students struggle to solve questions that apply mathematical equations, learning how students still memorize the material they are teaching, and students rarely study independently at home. According to [22] low learning outcomes are influenced by two internal and external factors. Internal factors that influence students ' interest in student learning and motivation in learning while external factors influencing the selection of methods and models of teaching by teachers, facilities and learning environment in the classroom.

\subsection{Hypothesis test results}

The hypothesis test is performed using nonparametric statistics with correlation rank spearman. Rank spearman test done with the help of SPSS 21 with a significance level of 5\%. Ho's acceptance criteria, if the significance of $<0.05$ then Ho is rejected. Test result correlation rank spearman presented in Table 8 .

Table 8 shows a significance value of 0.00 , with correlation coefficient for 0.292 . Ho was rejected means a significant link between scientific literacy and the learning outcomes of science students in the state Junior high school throughout Jaluko subdistrict, Jambi, Indonesia. The strength of the relationship between the two variables entered in weak correlation criteria. 


\begin{tabular}{|c|c|c|c|c|}
\hline & & & Scientific literacy & Learching Achievement \\
\hline \multirow{6}{*}{ Spearman's rho } & \multirow{4}{*}{ Scientific literacy } & Correlation Coefficient & 1.000 & $.292^{* *}$ \\
\hline & & Sig. & & .000 \\
\hline & & $\mathrm{N}$ & 138 & 138 \\
\hline & & Correlation Coefficient & $.292^{* *}$ & 1.000 \\
\hline & \multicolumn{2}{|c|}{ Learning Achievement Sig. } & .000 & . \\
\hline & & $\mathrm{N}$ & 138 & 138 \\
\hline \multicolumn{5}{|c|}{ **. Correlation is significant at the 0.01 level (1-tailed). } \\
\hline
\end{tabular}

\subsection{The correlation between scientific literacy and learning achievement}

This study gained the average scientific literacy score of 33.7 students with low category and the average score of study of science 21.5 with a very low category. The correlation test shows that there is a significant link between scientific literacy and the learning outcomes of science students in the state Junior high school throughout Jaluko subdistrict, Jambi, Indonesia. The results of this research are relevant to the research conducted by $[16,17]$ which shows that there is a positive relationship between scientific literacy skills and learning outcomes. The higher the skills of scientific literacy will be the higher the student learning outcomes. Previous researcher [23] stated that scientific literacy-based learning has an influence on increasing student learning outcomes.

In the form of students' scientific literacy skills, because students are unfamiliar with the problem of discourse, students are less accustomed to working on scientific literacy, and students have no trouble analyzing related problems in everyday life [24-26]. The low learning outcomes of science due to the lack of motivation and interest of students in studying science, many students forget the learning materials in the 7th and 8th grades and students lack time to work on the problem. [27] states the factors that affect scientific literacy is an internal factor consisting of physical and spiritual conditions, maturity/growth, intelligence, interests, exercises, learning habits, motivation and concepts of self and external factors, Consists of learning approaches, family conditions, teachers and how to teach them, and opportunities available. Scientific literacy is a fundamental ability that students must have in the face of a global era to meet the needs of life in a variety of situations. Scientific literacy must be an integral component of human resource development in the workforce [28]. Scientific literacy is a way of thinking and acting that encompasses students ' attitudes, skills, and knowledge [29]. Scientific literacy is the ability to understand science, communicate science, and apply the ability of science to solve problems [30].

Science learning must be oriented to the development of scientific literacy so that it can improve student learning outcomes. The development of scientific literacy can be done by applying approaches and learning models that train students to analyse scientific phenomena and environmental utilization as a learning resource. [31] Explaining science field visits can develop an interest in science that can lead to improved scientific literacy. Scientific approaches can improve the profile of students ' scientific literacy skills on the competencies and aspects of knowledge [32]. Improved scientific literacy would be better if during the experimental stage students were given investigative activities involving hypothesis verification and variable control such as in investigations, and STEM learning [33]. Learning through scientific investigations encourages students to develop skills through a view exchange so as to improve scientific literacy and attitudes towards science [34].

\section{CONCLUSION}

The results show the average score of scientific literacy 33.7 (low category) and the average score of science study results of 21.5 (very low). Correlation test results obtained significance value $0.000<0.05$ then Ho rejected so that it can be concluded that there is a significant relationship between scientific literacy with the results of learning science students in the state Junior High School throughout Jaluko subdistrict, Jambi, Indonesia. The magnitude of the correlation coefficient is 0.292 indicating a low correlation. Scientific literacy is an important skill that must-have for students. Students with scientific literacy skills will be able to apply the knowledge to solve the problems in their daily lives. Scientific literacy is a person's ability to use scientific knowledge and processes to make decisions related to the universe. Science learning must be oriented to the development of scientific literacy so that it can improve student learning outcomes. The development of science literacy can be done by applying approaches and learning models that train students to analyze scientific phenomena and environmental utilization as a learning resource. Learning through scientific investigations encourages students to develop skills through an exchange of views to improve science literacy and attitudes towards science. Learning by memorizing concepts, theories and laws alone cause students difficulty in applying the knowledge gained in daily life. 


\section{ACKNOWLEDGEMENTS}

The author would like to thank the Universitas Jambi for the help of funds in this study. The author also pronounces to the team that has helped in this research.

\section{REFERENCES}

[1] V.O. Ajayi., "Scientific literacy," Benue State University, pp. 1-11, Feb 2018.

[2] X. Liu., "Beyond scince literacy: Scince and the public," International Journal of Environmental \& Science Educantion, vol. 4, pp. 301-311, Dec 2008.

[3] OECD, The PISA 2003 assessment framework, Organization for Economic Cooperation and Development, 2003.

[4] P. Turiman et al., "Fostring the 21st centruy skills through scientific literacy and science process skills," Procedia Social and Behavioral Sciences, vol. 59, pp. 110-116, 2012.

[5] J. Holbrook, and M. Rannikmae, "The meaning of scientific literacy," International Journal of Environmental and Science Education, vol. 4, pp. 275-288, Jan 2009.

[6] OECD, Draf science framework PISA 2013, Organization for economic cooperation and development, 2015.

[7] A. Rusilowati, S. E. Nugroho, and S.M.E. Susilowati., "Development of science textbook based on scientific literacy for secondary school," Jurnal Pendidikan Fisika Indonesia, vol. 12, pp. 98-105, Mar 2016.

[8] A. Rusilowati, et al., "Developing an instrument of scientific literacy asessment on the cycle theme," International Journal of Environmental \&Science Education, vol. 11, pp. 5718-5727, Jun 2016.

[9] National Center for Education Statistics (NCES), "Highlights From TIMSS and TIMSS Andavanced 2015: Mathematics and Science Achievement of U.S. Students in Grades 4 and 8 and in Advanced Courses at the End of High School in an International Context, Washignton, DC, U.S Department Of Education, 2015.

[10] A. Rusilowati Sugianto, and A.D. Paramita, "The development of learning materials based science literacy on subject temperature and heat (in Bahasa)," Jurnal Pendidikan MIPA Phenomenon, vol. 7, pp. 58-69, 2017.

[11] W. Fitriani. Halrida, and I. Lestari., "The description of science literacy on inquiry model in subect reaction rate (in Bahasa)," Jurnal Pendidikan dan Pembelajaran, vol. 3, pp. 1-13, 2014.

[12] Z. Taurina., "Student's motivation and learning outcomes: Significant factors in internal study quality assurance system," International Journal for Cross-Discipkinary Subjects in Education, vol. 5, 2015.

[13] O.P. Wijaya, and I. Bukhori, "Effect of learning motivation, family factor, school factor, and community factor on stident learning oitcomes on productive subject," Jurnal Pendidikan Bisnis dan Manajemen, vol. 3, pp. 192-202, 2017.

[14] W. Widodo., "Assessing the readiness of student learning acitivity and learning outcome," Jurnal Pencerahan, vol. 10, pp. 81-94, Sep 2016.

[15] F. Fakhriyah., "Student's science literacy in the aspect of content?," Jurnal Pendidikan IPA Indonesia, vol. 6, pp. 81-87, Sep 2017.

[16] Andi et al., "The coorelation between science literacy and student learning achievement in acid base cocept (in Bahasa)," Jurnal Penelitian dan Pembelajaran IPA, vol. 1, pp. 16-25, 2019.

[17] D. Nugraheni, et al., "The impact of 5E learning cycle towards science literacy skill in material of the human nervous system (in Bahasa)," Jurnal Prodi Pendidikan Biologi, vol. 2, pp. 178-188, 2017.

[18] T. Perumal, Research Methodology, Malaysia, University Malaysia, Feb 2014.

[19] Ahmad et al.,"The coorelation between science literacy and student's self confidence in acid base subect (in Bahasa)," Jurnal penelitian dan pembelajaran IPA, vol. 1, pp. 16-15, 2015.

[20] I.D. Lestari., "Science literacy's impact towards student cognitive skill in ecosystem concept (in Bahasa)," Prosiding seminar nasional pendidikan FKIP UNTRIRTA, 2017.

[21] Utami, et al., "The importance of science literacy in junior high school science learning $21^{\text {st }}$ century (in Bahasa)," Indonesia Journal of Natural Science Education, vol. 1, pp. 24-29, 2019.

[22] Misyanto, "Factor analysis of the cause of low learning result on student grade 5 in mathematic subect 9 (in Bahasa)," Jurnal Anterior, vol. 15, pp. 144-150, Jun2016.

[23] Haristy, et al., "Learning based science literacy on material of electrolyte and non-electrolyte solution in SMA Negeri 1 Pontianak," Jurnal pendidik dan pembelajaran, vol. 1, pp, 2013.

[24] L. D. Purwani, F. Sudargo, and W. Surakusumah., "Analysis of student's scientific literacy skills through socioscientific issue's test on biodiversity topics," Journal of Physics: Conf. Series, 1013 (2018) 012019.

[25] G. Angraini.,"The analysis of science literacy skill on senior high school student at grade X in Solok City," Prosiding Mathematics and Sciences, pp. 161-170, 2014.

[26] Nadia, E. Suryawati, and M. Natalina., "The implementation of 5e learning cycle model to improve the scientific literacy skills of students in the science lessons class VIII.2 Of 21st Junior High School in Pekanbaru," vol. 6, pp. 1-15, Jun 2019.

[27] A. Syarifuddin., "The implementation of cooperative learning model and factors that affected it (in Bahasa)," Ta'dib: Journal of Islamic education, vol, 16, pp. 113-116, 2011.

[28] X. Liu., "Beyond science literacy: Science and the Public," International Journal of Environmental \& Science Education, vol. 4(3), pp. 301-311, Jul 2009.

[29] C. Yuenyong and P. Narjaikaew.,"Scientific literacy and Thailand science education," International Journal of Environmental \& Science Education, vol. 4(3), pp. 335-349, Jul 2009.

[30] Y.Yuliati, "Science literacy in science learning (in Bahasa)," JurnalCakrawala Pendas, vol. 3(2), pp. 21-28, Jul 2017.

The correlation between scientific literacy and science learning achievement at junior ... (Jufrida Jufrida) 
[31] M. Behrendt and T. Franklin. "A review of research on school field trips and their value in education," International Society of Educational Research, vol. 9, pp 235-245, 2014.

[32] A. Asyhari and R. Hartati. "Profile Improvement of students' literacy skills through scientific learning (in Bahasa)," Jurnal Ilmiah Pendidikan Fisika Al-BiRuNi, vol. 4(2), pp. 179-191, 2015.

[33] Y. Herlanti, Y. Mardiati, Rahmawati, et al., "Finding learning strategy in improving science literacy," Jurnal Penelitian dan Pembelajaran IPA, vol. 5(1), pp. 59-71, 2019.

[34] M. Genç, "The effect of scientific studies on students' scientific literacy and attitude," OndokuzMayis University Journal of Faculty of Education, vol. 34(1), pp. 141-152, 2015. 